\title{
Research on the Inheritance and Development of Thangka under the Mode of Art Management
}

\author{
Qinghua Hu \\ School of Art, Qinghai Nationalities University, Xining, China \\ Email: h_qh110@163.com
}

How to cite this paper: Hu, Q. H. (2021). Research on the Inheritance and Development of Thangka under the Mode of Art Management. Art and Design Review, 9, 74-79.

https://doi.org/10.4236/adr.2021.91006

Received: January 4, 2021

Accepted: February 22, 2021

Published: February 25, 2021

Copyright $\odot 2021$ by author(s) and Scientific Research Publishing Inc. This work is licensed under the Creative Commons Attribution International License (CC BY 4.0).

http://creativecommons.org/licenses/by/4.0/

\begin{abstract}
Thangka is an important part of the intangible cultural heritage of Qinghai-Tibet region. At present, The protection and development of this traditional art are valued and promoted, while we study its artistic characteristics and inheritance law, we should also actively explore the government, artists, educational institutions and other integration of multiple development paths, The principles and methods of art management activities play a guiding role in the inheritance and development of traditional Thangka art.
\end{abstract}

\section{Keywords}

Thangka, Place of Origin, Government, Entertainer, Educational Institution

\section{The Current Living State and Marketing Mode of Folk Thangka}

The initial consumer group of Thangka is the need of temple worship and chanting sutras for Tibetan Buddhist temples and believers. Thangka, as a work of art, has entered the art market and heated up rapidly in the past 20 years. With the quickening of the international cultural exchange and the deepening of the national intangible cultural heritage protection, the national folk art also shows its strong vitality and fascinating mystery. Thangka has gradually become one of the most popular art collections and its artistic value is gradually recognized by people, all due to its complex production techniques and fine painting skills. However, with the rapid development of world economic integration and modernization, the ecological balance of those precious cultures with primitive forms and historical connotations is being destroyed. In the face of economic temptation, artists, the creative subjects of Thangka art, have gradually lost their earnest protection and reasonable development of rich cultural resources. The low-cost 
and quickly produced popular works have flooded the Thangka art market. Artists fight alone, the marketing method is relatively simple, which is dominated by the order mode, mostly for the temple, personal custom. The rest of the artists wait for clients to come to them to sell finished products or make reservations.

The inheritors that exist in the current Thangka art market can produce and judge the quality of the works, but they will not manage and market them. Understands how to operate for what is a real work of art is not very clear, this needs to establish an artist, work, positive interaction between dealers and collectors, art management and other managers, first of all our needs for art creation, production and dissemination has a basic judgment, this is the prerequisite of management and Thangka art market.

\section{Give Full Play to the Advantages of Origin and Explore the Art Management Mode of Folk Thangka}

The origin of a product affects the consumer's evaluation of the product, thus affecting the purchase tendency, the overall cognition of the product produced in a certain region, and the long-term impression and feeling of the product. For example, Tongren County, Huangnan Tibetan Autonomous Prefecture, Qinghai Province, where people have been engaged in Thangka drawing for generations, is recognized as the "hometown of Chinese Thangka art". The works of Thangka are exquisite and beautiful, with high artistic value, representing the highest level of Thangka. The origin effect is also the most important content in art management, which is reflected in the level of art display. "The art exhibition for the purpose of sales is not carried out in a chaotic situation. Careful preparations should be made before presenting an object to a prospective buyer. The scene where the goods are placed and the reputation of the place where they are found are of great importance to the buyer's estimation of quality, value and authenticity. Presentation is a key factor in sales success. If the buyer knows that the place where the article is found is its original and 'natural' position, then it may be the place where it is made and used, and it is unlikely that there will be a forgery (George \& Fred, 2010).” The establishment of Regong cultural and ecological protection experimental zone in 2008 to protect the origin of artworks and give full play to the advantages of the original place is not only to protect the context of traditional art, but also to put an end to counterfeiting and effective measures to restore the original appearance. "If the human element is the most important element in the general production activities, then in the art production, the human element is more valuable. The production of many works of art depends on the level of art producers and the artistic feeling and experience of artists $(\mathrm{Lu}$, 2004)." At present, the consumption groups of Thangka artworks show a multi-level situation, which is mainly manifested in three aspects: first, high-quality oriented, mainly for collection and investment in art works; decond, for excellent works, mainly for art trading; third, for mediocre works, mainly as special products gifts or tourism souvenirs. "Because everyone's preferences are differ- 
ent, it is not easy for others to accurately grasp one's judgment on the value of an art. What's more, the value of art is actually one's internal and subjective evaluation of art (Ma, 2008)."

\section{Establish the Joint Efforts and Positive Interaction between the Government, Artists' Organizations and Schools}

\subsection{The Government}

1) Since artistic products are going to enter the market, they should appear in the form of commodities. The art market is not ready-made, it is mostly scattered, the form is not standard. Art exhibition and art exposition are important ways to promote the market circulation of art works. The original form of "art exhibition" is also for display and sales service, with the functions of exhibition planning, collection, research and education. The government should provide more opportunities for exhibitions in two dimensions of time and space, so that inheritors can feel the popular works in the process of exhibition, have a more intuitive understanding of the demand of Thangka art market, and then play the role of guiding the creation through exhibition.

2) Collect cultural heritage and contemporary representative works. To sort out the origin and origin of different styles and schools of Thangka, build relevant image data database, classify endangered cultural relics, classic works and works with contemporary characteristics, and build an accurate and authoritative data platform to achieve open sharing.

3) The establishment of official channels and online sales platform for art distribution, on the one hand, to ensure the quality, on the one hand, to end the artist's family "fight alone" to give full play to the advantages, grasp the trend, overall coordination, form a resultant force, give full play to the leading role of the government and the positive role of the market.

4) Strengthen the supervision of the folk art market, crack down on fake and shoddy works, and safeguard the honor of folk artists and their works. Counterfeits are copies or imitations that pretend to be authentic. In the Thangka art market, it basically comes from the imitation of authentic products. Religious service is the original function of Thangka. Because of this, the form of composition, the content of works and the techniques of painting are often fixed and have a strong stylized form, which also provides convenience for mass reproduction and imitation. "For most genuine works of art, the supply is always limited. When people's demand for a certain kind of art is increasing, and the increase in supply is difficult to meet the increase in demand, the market price of this kind of art may rise. But even so, it often fails to meet the needs of the art market. If collectors only want to get psychological satisfaction and spiritual enjoyment, then copies and imitations can also better meet their needs in this respect $(\mathrm{Ma}$, 2008)." Wu Pingan, a famous folklorist, said that the value of intangible cultural heritage is a living traditional culture, protection is protection, and protection 
itself is value. It is an important content of Thangka protection to effectively supervise the phenomenon of counterfeiting masterpieces and cultural relics.

5) To establish an effective property rights protection system, more use of the sense of honor and sense of achievement to mobilize the enthusiasm of artists. Promote the branding construction consistent with artists' painting styles and regional characteristics. Help to improve the inheritor's family workshop, painting academy, study institute to enterprise, corporate mode transformation.

\subsection{The Role of Folk Artists (Art Folk Organizations)}

1) To provide advice and consultation on cultural policies to the government. Intangible cultural protection is a long-term and arduous work, to the competent department of culture with artists, artists organizations to share, to maintain the integrity of the original ecological culture is to protect the important and difficult, from the perspective of to inheriting the artificial center to understand the intangible, and encourage the creation and change is the law of inheritance, ensure the survival of artist personality and art reproduction of labor force. Artist organization should play the role of bridge and link between management department and artist.

2) Carry out "peer review" of artistic achievements. Conduct professional and routine assessment of artistic creation and cultural development, and determine government funding and support for cultural priority projects based on the assessment. "An index can bring several benefits to arts organisations. First, progress in achieving the objectives and objectives of the institution can be measured against more objective benchmarks. Without comparison, the evaluation index has no value. The best approach is to compare it with the past performance, trends and long-term position of the agency: planning objectives, that is, the budget against the actual income and expenditure. Second, the relevant strengths and weaknesses can be identified, which helps to assist decision-making from the perspective of resource allocation. The real use of the evaluation index is not as a standard of evaluation, but in its diagnostic value. This requires monitoring of key indicators where problems can be warned of. Third, the index can encourage and motivate employees: evaluation management helps to understand such issues as what makes an organization the most attractive to an audience (Yu, 2008)."

3) The organization of peer exchange, skill competition. "In the handicraft industry of the traditional society, the technical standard of handicraft has always existed, and its consummate degree is the ruler of its value (Qiu, 2016)." Organize and drive the communication of styles and techniques between artists and different schools of painting, put aside utility and concentrate on painting, so that "universal and simple copying" can be transformed into creative ideas. Thangka painting competitions are held regularly to improve artists' professional skills and consolidate their basic skills through skill competition, which is not only a self-display of artists and works, but also a way to promote learning through competition and carry forward the spirit of national culture. To achieve 
the goal of improving cognition, improving technique and improving innovation ability.

\subsection{Educational Institutions}

Is the best way to protect heritage, the school is the best carrier of inheriting traditional culture, the traditional Thangka art combined with school fine arts education, is beneficial to the effect of the Thangka non-material cultural heritage protection, education institutions should combine law school fine arts education teaching research and exploration, to find a suitable for Thangka good docking with the school fine arts education, compatible with the development of the teaching thought and teaching method. Realize the sustainable development of culture, the content innovation is the fundamental, and innovation is the soul element and innovative elements, knowledge content production with talent to promote the development of cultural industry is an indisputable fact that, in the school academic study, training specialized personnel in artistic characteristics, formation of talent growth and the benign interactive relationship between the industrial development. Education institutions as "incubator" of talent, should by previous culture oriented cultivation special artistic talents to adapt to the culture industry law of development and industry in a variety of quality of the fusion of demand management in the field of personnel, training in the art business has introduced and explained, publicity and packaging art and artists, study the specific art commercial phenomenon, research situation and tendency of an art market, future of one or some sort of commercial mediation role of talent, Through the development of cultural resources and the artistic production of aesthetic creation, schools can promote the renewal of ideas and the basic research of culture and art and the original innovation in the frontier fields.

At present, cultural departments and universities jointly carry out the training of non-hereditary people, which has three effects: school teachers can strengthen the academic research on the intangible cultural heritage; through this platform, non-hereditary inheritors can learn how to develop and innovate, and improve their cultural and artistic accomplishment and aesthetic ability. The inheritors can also learn from each other in different styles and skills. The training of inheritors should conform to the nature of education, rather than impose.

Inheritance is the best way to protect Thangka art, and the trend of Thangka art should be refined rather than popular. Explore the mode of Thangka art management, protection and development goal is to art and technology, the rural economy and urban economy, education and production, the folk art with real life, constantly in the process of transformation innovation, abandoning the inheritance with new times connotation and modern form of expression, complement, expand and improve constantly, make the Thangka, the ancient religious art one of the most basic national folk art cultural genes and adapted to contemporary culture, in harmony with the modern society, enhance the connotation of our nation, let's take on guard, spread and carry forward the Chinese tradition art, Pray for the protection, inheritance and innovation of Thangka art. 


\section{Conflicts of Interest}

The author declares no conflicts of interest regarding the publication of this paper.

\section{References}

George, E. M., \& Fred, R. M. (2010). Cultural Exchange: Reshaping Art and Anthropology. Nanning: Guangxi Normal University Publishing House.

Lu, Y. (2004). Art Management. Shanghai: Shanghai Music Publishing House.

Ma, J. (2008). Economics of Art Market. Beijing: China Times Economic Publishing House.

Yu, D. (2008). Introduction to Art Management. Beijing: Higher Education Publishing House.

Qiu, C. (2016). Theory and Criticism of Arts and Crafts. Beijing: Culture and Art Publishing House. 